\title{
A Novel Approach to Cold Vapor Generation for the Determination of Mercury in Biological Samples
}

\author{
Eder José dos Santos, ${ }^{*, a}$ Amanda Beatriz Herrmann, ${ }^{a}$ Vera Lúcia Azzolin Frescura, ${ }^{b}$ \\ Ralph Edward Sturgeon ${ }^{c}$ and Adilson José Curtius ${ }^{b}$
}

anstituto de Tecnologia do Paraná, TECPAR, 81350-010 Curitiba-PR, Brazil

${ }^{b}$ Departamento de Química, Universidade Federal de Santa Catarina, 88040-900 Florianópolis-SC, Brazil

${ }^{b}$ Institute for National Measurement Standards, National Research Council Canada, ON K1A OR9, Ottawa, Canada

\begin{abstract}
Propõe-se uma nova maneira de gerar vapor de mercúrio em altos valores de $\mathrm{pH}$ pela adição de $\mathrm{NaOH}$ ou de outra base a uma solução contendo íons de mercúrio, sem utilizar redutor, como $\mathrm{NaBH}_{4}$ ou $\mathrm{SnCl}_{2}$. Após dissolução total da amostra em sistema de microondas fechado, empregando $\mathrm{HNO}_{3}$ e $\mathrm{H}_{2} \mathrm{O}_{2}$, o pH da solução da amostra é elevado para 13 com NaOH. Após 90 min de repouso, o vapor frio é transportado até o plasma por um fluxo de gás argônio. O Hg é determinado em 253,652 nm em um espectrômetro de emissão óptica com plasma indutivamente acoplado com configuração axial. O procedimento foi aplicado a cinco amostras biológicas certificadas obtendose um limite de detecção $(3 \mathrm{~s}, n=10)$ de $0,04 \mu \mathrm{g} \mathrm{g}^{-1}$ para uma massa da amostra de $0,5 \mathrm{~g} \mathrm{em}$ um volume final de $50 \mathrm{~mL}$. A calibração foi realizada com soluções padrão aquosas em $\mathrm{NaOH}$ $0,1 \mathrm{~mol} \mathrm{~L}^{-1}$. O procedimento foi eficiente, com recuperações dos valores certificados entre $85 \mathrm{e}$ $113 \%$, demonstrando concordância entre o valor encontrado e o certificado para um nível de $95 \%$ de confiança (teste- $t$ ). A precisão apresentou resultados aceitáveis com desvios padrão relativos de 7 a 9\%. Mercúrio a partir de espécies orgânicas em solução, não foi detectado; somente $\mathrm{Hg}^{2+} \mathrm{em}$ solução produz sinal. O procedimento é novo, simples, pode permitir estudos de especiação e serve para demonstrar liberação de vapor de mercúrio de soluções aquosas em altos valores de $\mathrm{pH}$.
\end{abstract}

A novel approach to the generation of mercury vapor at high $\mathrm{pH}$ by the simple addition of $\mathrm{NaOH}$ or other base to a solution containing mercury ions is described. Subsequent addition of another reducing agent, such as $\mathrm{NaBH}_{4}$ or $\mathrm{SnCl}_{2}$, is unnecessary. Following total dissolution of sample using $\mathrm{HNO}_{3}$ and $\mathrm{H}_{2} \mathrm{O}_{2}$ in a closed microwave vessel, the $\mathrm{pH}$ of the sample solution is increased to 13 by the addition of $\mathrm{NaOH}$. After standing for $90 \mathrm{~min}$ in a closed vessel, the $\mathrm{Hg}^{0}$ is directed to the plasma by a flow of argon. Emission from mercury is measured at $253.652 \mathrm{~nm}$ by an axial view inductively coupled plasma optical emission spectrometer (ICP OES). The procedure was applied to five certified biological samples, yielding a detection limit $(3 \mathrm{~s}, n=10)$ of $0.04 \mu \mathrm{g} \mathrm{g}^{-1}$ based on a nominal sample mass of $0.5 \mathrm{~g}$ in a final volume of $50 \mathrm{~mL}$. Calibration was achieved using simple aqueous standard solutions containing $0.1 \mathrm{~mol} \mathrm{~L}^{-1} \mathrm{NaOH}$. The procedure was efficient, with determined values lying in the range of $85-113 \%$ of the certified values, showing good agreement at the $95 \%$ confidence level ( $t$-test). The precision was fit for purpose, with relative standard deviations ranging from 7 to $9 \%$. Organomercury species in solution were not detected; only $\mathrm{Hg}^{2+}$ in solution produces a signal. This new procedure provides for a simple approach to quantitation (and potentially speciation).

Keywords: mercury, alkaline $\mathrm{pH}$, inductively coupled plasma optical emission spectrometry, cold vapor generation, biological samples

\section{Introduction}

The chemical transformation of an analyte species to a volatile form is known as chemical vapor generation

*e-mail: eder@tecpar.br
(CVG). The main advantages of CVG are the separation of the analyte from the matrix and high sample introduction efficiency, resulting in enhanced sensitivity, selectivity and detection limits. ${ }^{1}$ This is a widely utilized methodology in atomic spectrometry for the determination of trace and ultra-trace concentrations of elements such as $\mathrm{As}, \mathrm{Sb}, \mathrm{Bi}$, 
$\mathrm{Ge}, \mathrm{Pb}, \mathrm{Hg}$, Se, Te and Sn. Currently, $\mathrm{NaBH}_{4}$ remains the most popular reagent for $\mathrm{CVG}$, forming volatile species of not only the aforementioned elements, but also of $\mathrm{Ag}, \mathrm{Au}, \mathrm{Cd}, \mathrm{Cu}, \mathrm{In}, \mathrm{Ni}, \mathrm{Pt}, \mathrm{Rh}, \mathrm{Tl}$, and $\mathrm{Zn}$ with important analytical applications. ${ }^{1-4}$ Several alternative means of $\mathrm{CVG}$, not using $\mathrm{NaBH}_{4}$, have also been proposed: electrochemical vapor generation; ${ }^{5}$ alkylation reactions, such as those using Grignard reagents (e.g., for tributyltin with pentylmagnesium bromide ${ }^{1}$ ) and, more recently, photochemical vapor generation with UV irradiation. Examples of the latter include generation of volatile species of $\mathrm{Se}(\mathrm{IV})$ in formic, acetic and propionic acids (with formation of $\mathrm{SeH}_{2}$, dimethylselenium and diethylselenium respectively ${ }^{6}$ ) and of $\mathrm{Ni}$ by reaction with $\mathrm{CO}$ (yielding $\mathrm{Ni}(\mathrm{CO})_{4}{ }^{7}$ ). There is a particular interest in the determination of $\mathrm{Hg}$ because of its toxicity, mobility and ability to accumulate in various organisms. Cold vapor (CV) generation coupled to atomic absorption (AAS) or atomic fluorescence spectrometry (AFS) are the techniques most frequently used for detection. ${ }^{8-10}$ In addition, photochemical vapor generation ${ }^{11-13}$ and ultrasound-assisted vapor generation ${ }^{14,15}$ have recently been proposed.

We have found that mercury ions in aqueous solution can be reduced to elemental mercury by simply increasing the $\mathrm{pH}$ of the solution through addition of $\mathrm{NaOH}$ or other base, without the need for any additional reducing agent. Taking into account this finding, an analytical method for the determination of mercury by CV-ICP OES is presented herein.

\section{Experimental}

\section{Instrumentation}

All measurements were made using a simultaneous axial view ICP OES spectrometer, model VISTA PRO (Varian, Mulgrave, Australia), coupled to an on-line continuous vapor generation system (Varian, model VGA-76P). Within the VGA-76P system, the argon gas supply is divided into two branches by a suitable " $T$ " piece. One branch is controlled by a solenoid stop valve and argon gas to the inlet side of the reaction coil. The other branch supplies argon gas directly through the gas/liquid separator. With this system, only the sample line was employed, using 2.90 mm i.d medical grade PVC purple/black tubing (Kendall No. 1160549160) for the sample treated with $\mathrm{NaOH}$. A scheme illustrating the vapor generation system coupled to the ICP OES spectrometer is shown in Figure 1. The experimental conditions are summarized in Table 1. Peak height emission intensities were measured at $253.652 \mathrm{~nm}$. Argon (99.996\% purity, White Martins, São Paulo, Brazil) was used. Samples were totally digested in a closed CEM microwave system (model MDS 2100, Matthews, NC, USA). A Shimadzu model AA-6601F single beam atomic absorption spectrometer (Nakagyo-Ku, Kyoto, Japan) equipped with deuterium lamp background correction and Hg hollow cathode lamp L233 from Hamamatsu Photonics K.K. (Shizuoka, Japan) was used to verify the generation of $\mathrm{Hg}^{0}$.

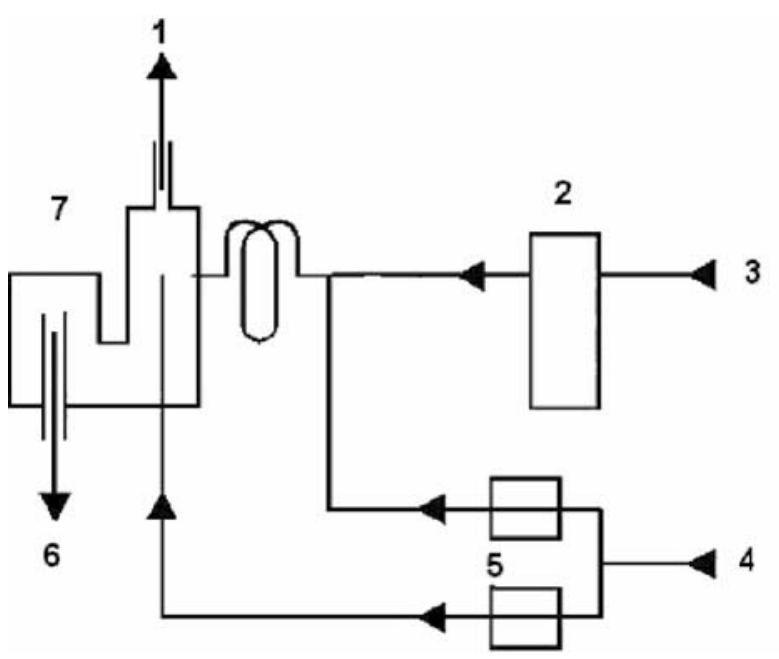

Figure 1. Scheme of chemical vapor generation system (Varian model VGA-76P): 1. to the ICP OES; 2. peristaltic pump (50 rpm); 3. sample (flow rate of $\left.8 \mathrm{~mL} \mathrm{~min}^{-1}\right)$; 4. carrier gas flow rate $\left(120 \mathrm{~mL} \mathrm{~min}^{1}\right)$; 5 . flow controller; 6. drain (Nalgene tubing); 7. phase separator.

Table 1. Instrumental parameters for ICP OES and cold vapor generation

\begin{tabular}{lc}
\hline \multicolumn{2}{c}{ ICP OES } \\
\hline Radiofrequency & $40 \mathrm{MHz}$ \\
Radiofrequency power & $1.2 \mathrm{~kW}$ \\
Plasma gas flow rate & $15.0 \mathrm{~L} \mathrm{~min}^{-1}$ \\
Auxiliary gas flow rate & $1.5 \mathrm{~L} \mathrm{~min}^{-1}$ \\
Replicate read time & $3 \mathrm{~s}$ \\
Stabilization time & $35 \mathrm{~s}$ \\
Replicates & 4 \\
Torch & Quartz for axial view \\
Analytical line & $253.652 \mathrm{~nm}^{-}$ \\
Vapor generator & \\
Sample flow rate & $120 \mathrm{~mL} \mathrm{~min} \mathrm{~min}^{-1}$ \\
Carrier gas flow rate &
\end{tabular}

\section{Reagents and materials}

All chemicals were of analytical grade, unless otherwise specified. High purity water (resistivity of $18.2 \mathrm{M} \Omega \mathrm{cm}$ ) was de-ionized in a Milli-Q system (Bedford, MA, USA). The following reagents were used: Suprapur ${ }^{\circledR} 65 \%$ v/v $\mathrm{HNO}_{3}$ (Merck, Darmstadt, Germany No. 1.00441.1000), sodium hydroxide (Merck, No. 1.06498.1000), 30\% (v/v) hydrogen 
peroxide (Merck No. 1.07210.1000), $1000 \mu \mathrm{g} \mathrm{mL} \mathrm{L}^{-1} \mathrm{Hg}$ standard solution (Merck No. 1.19795.0500). A Thimerosal stock solution, containing $100 \mu \mathrm{g} \mathrm{L}^{-1}$ of $\mathrm{Hg}$, was prepared by dissolving the salt $\left(\mathrm{C}_{9} \mathrm{H}_{9} \mathrm{HgNaO}_{2} \mathrm{~S}\right.$ ) (Merck No. 8.17043.0100) in water. A methylmercury chloride stock solution was prepared by dissolving $\mathrm{CH}_{3} \mathrm{HgCl}$ (Fluka, $98 \% \mathrm{~m} / \mathrm{m}$ purity) in ethanol (Merck No. 1.00983.1000).

The following certified reference materials were analyzed: DOLT-2 (Dogfish Liver), TORT-2 (Lobster Hepatopancreas) and DORM-1 (Dogfish Muscle) from the National Research Council Canada (NRCC, Ottawa, Ontario, Canada); BCR 186 (Lyophilized Pig Kidney), from the European Community Bureau of Reference (Brussels, Belgium); SRM 1566a (Oyster Tissue) from the National Institute of Standards and Technology (NIST, Gaithersburg, MD, USA).

\section{Procedures}

Nominal 0.1-0.5 g samples of biological tissue were weighed into each microwave vessel (Advanced Composite Vessel, from CEM), followed by the addition of $5 \mathrm{~mL}$ concentrated $\mathrm{HNO}_{3}$ and $2.5 \mathrm{~mL}$ of $30 \%(\mathrm{v} / \mathrm{v}) \mathrm{H}_{2} \mathrm{O}_{2}$. After standing for $1 \mathrm{~h}$, the samples were digested in the microwave system in accordance with EPA method SW 846-3051 (closed vessel). The resultant clear solutions were transferred to $50 \mathrm{~mL}$ volumetric flasks. Sufficient $\mathrm{NaOH}$ was added to each digested sample solution to achieve $\mathrm{pH} 13$ (reached when the $\mathrm{NaOH}$ concentration was typically $0.1 \mathrm{~mol} \mathrm{~L}^{-1}$ ); the volume was made up with high purity water and the flask was capped. After standing for $90 \mathrm{~min}$ in the closed flask under normal lab conditions, the sample (or standard calibration solutions which had been similarly mixed with the base) was introduced into the on-line generation system and emission from $\mathrm{Hg}$ was measured. Quantitation was performed against simple aqueous calibration solutions containing $1.0-20 \mu \mathrm{g} \mathrm{L}^{-1} \mathrm{Hg}^{2+}$. A reagent blank solution was run parallel to the determination and its result was taken into consideration. To study the effect of temperature, a solution containing $10 \mu \mathrm{g} \mathrm{L}^{-1}$ of $\mathrm{Hg}^{2+}$ in $0.1 \mathrm{~mol} \mathrm{~L}^{-1} \mathrm{NaOH}$ was placed in a closed vessel and left to stand for 90 min under normal lab conditions. The solution was then transferred to a beaker, a thermometer inserted, and the solution then placed on a heating plate. When a predetermined temperature was reached, the solution was immediately aspirated into the on-line vapor generator. Experiments were also undertaken in the dark to assess the influence of ambient laboratory lighting. After the addition of the $\mathrm{NaOH}$ solution to a $10 \mu \mathrm{g} \mathrm{L}^{-1} \mathrm{Hg}^{2+}$ standard, the container was covered with aluminum foil and left to stand for $90 \mathrm{~min}$ in the dark before being introduced into the on-line vapor generator.

\section{Results and Discussion}

This study initially utilized a tetramethylammonium hydroxide (TMAH) medium for vapor generation, resulting in the production of a signal for mercury after adjusting the solution $\mathrm{pH}$ to 13 with $\mathrm{NH}_{4} \mathrm{OH}$. Although it was then concluded that this reagent was reducing mercury in solution, it was subsequently determined that it was the $\mathrm{pH}$ change and not the TMAH that was responsible for production of mercury vapor. Using only TMAH, without adding another base to change the $\mathrm{pH}$, a small intensity signal is obtained for mercury. However, if TMAH is added until $\mathrm{pH}=13$, the signal intensity is relatively high.

\section{Effect of $p H$}

Aqueous solutions containing $10 \mu \mathrm{g} \mathrm{L}^{-1}$ of $\mathrm{Hg}^{2+}$ were adjusted to different $\mathrm{pHs}$ by addition of $\mathrm{NaOH}$ or $\mathrm{HNO}_{3}$. As shown in Figure 2, the signal increases with $\mathrm{pH}$, most intensively in the range $\mathrm{pH}=11$ to 13 . We do not yet know the mechanism of reduction arising by the addition of $\mathrm{NaOH}$ and therefore currently have no explanation for this observation.

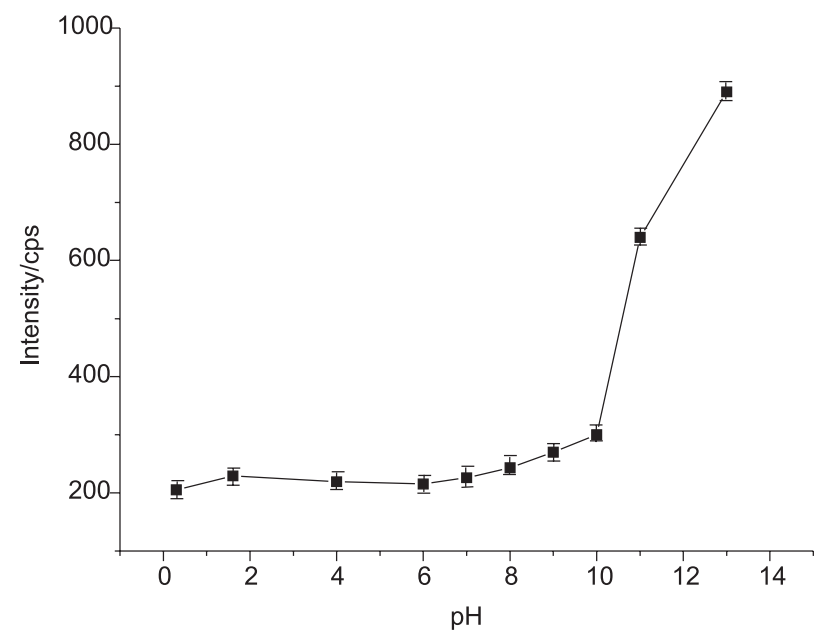

Figure 2. Effect of $\mathrm{pH}$ on signal intensity from an aqueous standard solution containing $10 \mu \mathrm{g} \mathrm{L}^{-1} \mathrm{Hg}^{2+}$ with $\mathrm{pH}$ adjusted with $\mathrm{NaOH}$ and/or $\mathrm{HNO}_{3}$. Error bars represent standard deviation of three replicate measurements.

\section{Effect of time}

Figure 3 shows the signal intensity arising from a $10 \mu \mathrm{g} \mathrm{L}^{-1}$ solution of $\mathrm{Hg}^{2+}$ containing $0.1 \mathrm{~mol} \mathrm{~L}^{-1} \mathrm{NaOH}$ $(\mathrm{pH}=13)$ as a function of the reaction time. It is clear that an incubation period of $90 \mathrm{~min}$ is required to obtain a maximum signal. This time was adopted for the standard and for the sample solutions. The vessel was kept capped during the incubation time. 


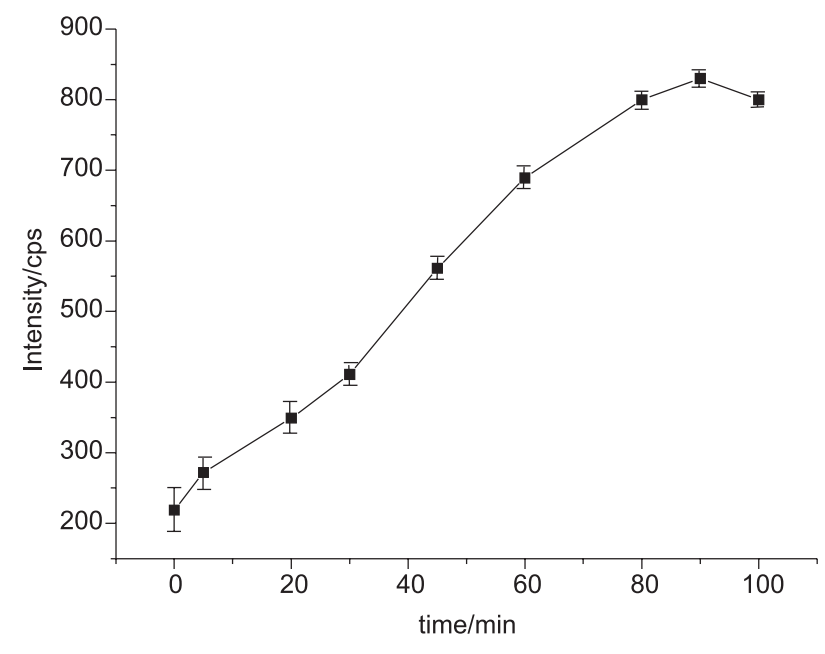

Figure 3. Effect of incubation time on signal intensity from an aqueous standard solution containing $10 \mu \mathrm{g} \mathrm{L}^{-1} \mathrm{of} \mathrm{Hg}^{2+}$ in $0.1 \mathrm{~mol} \mathrm{~L}^{-1} \mathrm{NaOH}$. Error bars represent the standard deviation of three replicate measurements.

\section{Effect of the carrier gas flow rate}

Different carrier gas flow rates in the range 60-180 $\mathrm{mL} \mathrm{min}^{-1}$ were tested, again for a solution containing $10 \mu \mathrm{g} \mathrm{L}^{-1} \mathrm{Hg}^{2+}$ in $0.1 \mathrm{~mol} \mathrm{~L}{ }^{-1} \mathrm{NaOH}$. Measurements commenced 90 min after the addition of the $\mathrm{NaOH}$. The results in Figure 4 show that response increases rapidly

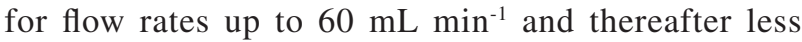
intensively. A flow rate of $120 \mathrm{~mL} \mathrm{~min}^{-1}$ was adopted for further study as this was optimal for efficient operation of the phase separator and the transfer of $\mathrm{Hg}^{0}$ from the solution. Without a carrier gas, the signal intensity is the same as for the blank, indicating that insufficient $\mathrm{Hg}^{0}$ is transferred from the solution to the plasma to produce a signal under this condition.

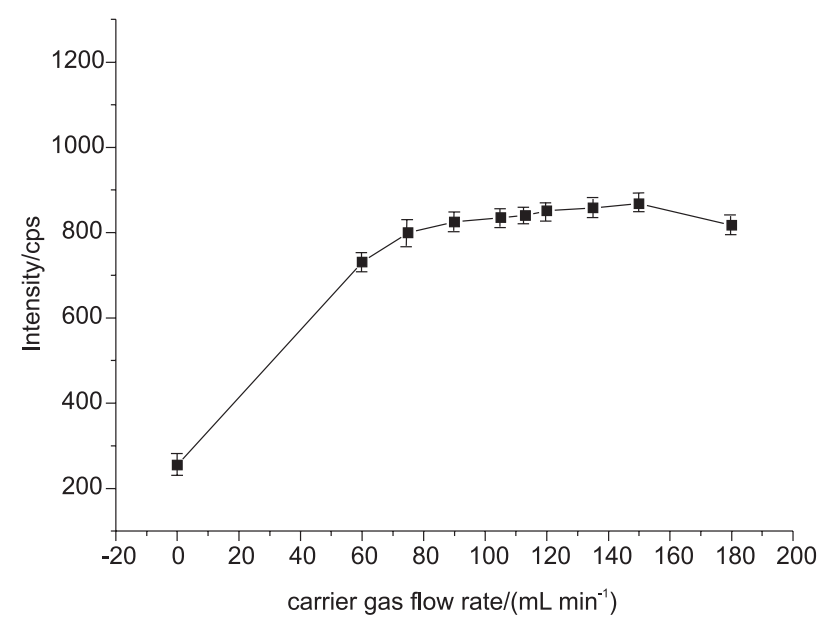

Figure 4. Effect of carrier gas flow rate on signal intensity from an aqueous standard solution containing $10 \mu \mathrm{g} \mathrm{L}^{-1}$ of $\mathrm{Hg}^{2+}$ in $0.1 \mathrm{~mol} \mathrm{~L}^{-1} \mathrm{NaOH}$. Error bars represent the standard deviation of three replicate measurements.

\section{Effect of visible light}

The signal intensity arising from a solution containing $10 \mu \mathrm{g} \mathrm{L}^{-1} \mathrm{Hg}^{2+}$ in $0.1 \mathrm{~mol} \mathrm{~L}^{-1} \mathrm{NaOH}$, prepared and measured in the dark (flask covered with aluminum foil in the dark) was identical to that arising from a solution prepared under normal laboratory illumination conditions, demonstrating that the reduction of mercury is not influenced by light.

\section{Effect of temperature}

Figure 5 shows the signal intensity arising from a solution containing $10 \mu \mathrm{g} \mathrm{L}^{-1} \mathrm{Hg}^{2+}$ in $0.1 \mathrm{~mol} \mathrm{~L}^{-1} \mathrm{NaOH}$ as a function of the temperature of the reaction vessel. The signal intensity increases up to $50{ }^{\circ} \mathrm{C}$, decreasing for higher temperature. Certainly, mercury is lost from the flask during heating. The loss is especially noticeable for temperatures higher than $50{ }^{\circ} \mathrm{C}$. Increased temperature likely favors liberation of the vapor from the solution due to decreased solubility. ${ }^{16}$ Better precision was obtained at room temperature, which was adopted for all further experiments.

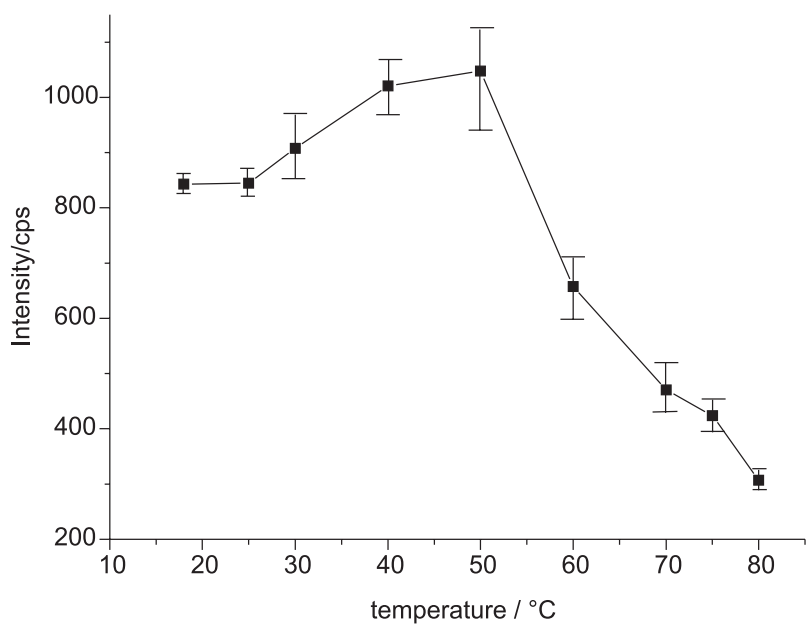

Figure 5. Effect of temperature on signal intensity from an aqueous standard solution containing $10 \mu \mathrm{g} \mathrm{L}^{-1}$ of $\mathrm{Hg}^{2+}$ in $0.1 \mathrm{~mol} \mathrm{~L}^{-1} \mathrm{NaOH}$. Error bars represent the standard deviation of three replicate measurements.

\section{Figures of merit}

Calibration curves, using $\mathrm{Hg}$ standard solutions spanning the concentration range $1.0-20 \mu \mathrm{g} \mathrm{L}^{-1}$, were obtained using the selected conditions. The linear correlation coefficient was 0.997 , and the limit of detection (LOD), defined as 3 times the standard deviation of 10 measurements of the blank divided by the slope of the calibration curve, was $0.04 \mu \mathrm{g} \mathrm{g}^{-1}$ for $0.5 \mathrm{~g}$ of the solid sample in a final volume of $50 \mathrm{~mL}$. This LOD was adequate for the analysis of the certified biological samples. 
Table 2. Analytical results for biological samples, $\mu \mathrm{g} \mathrm{g}^{-1}(n=3)$

\begin{tabular}{|c|c|c|c|c|}
\hline sample & certified & found & recovery $(\%)$ & $\operatorname{RSD}(\%)$ \\
\hline DOLT-2 & $2.14 \pm 0.28$ & $2.35 \pm 0.22$ & 110 & 9 \\
\hline TORT-2 & $0.27 \pm 0.06$ & $0.23 \pm 0.02$ & 85 & 9 \\
\hline DORM-1 & $0.798 \pm 0.074$ & $0.745 \pm 0.05$ & 93 & 7 \\
\hline BCR 186 & $1.97 \pm 0.04$ & $2.24 \pm 0.18$ & 113 & 8 \\
\hline SRM 1566a & $0.0642 \pm 0.0067$ & $0.069 \pm 0.005$ & 107 & 7 \\
\hline
\end{tabular}

\section{Generation of $\mathrm{Hg}^{0}$}

In order to verify the formation of $\mathrm{Hg}^{0}$ by the addition of $\mathrm{NaOH}$, as opposed to other $\mathrm{Hg}$ species that would be decomposed in the plasma, measurements were also made based on cold vapor atomic absorption spectrometry using a quartz cell at room temperature and the same VGA-76P vapor generation equipment. A calibration curve was obtained, demonstrating that $\mathrm{Hg}^{0}$ is in fact formed.

\section{Analytical application}

The procedure was applied to the analysis of five biological certified reference materials. The results are summarized in Table 2 . The recoveries of the certified values, between 85 and $113 \%$, were acceptable and all results were in agreement with the certified values in accordance with a $t$-test at the $95 \%$ level of confidence. ${ }^{17}$ Precision was acceptable, with relative standard deviations (RSD) in the range 7-9\%.

\section{Additional studies}

Possible vapor generation of $\mathrm{Ag}, \mathrm{Al}, \mathrm{As}, \mathrm{B}, \mathrm{Ba}, \mathrm{Be}$, $\mathrm{Ca}, \mathrm{Cd}, \mathrm{Co}, \mathrm{Cr}, \mathrm{Cu}, \mathrm{Fe}, \mathrm{K}, \mathrm{Li}, \mathrm{Mg}, \mathrm{Mn}, \mathrm{Mo}, \mathrm{Ni}, \mathrm{P}, \mathrm{Pb}$, $\mathrm{Sb}, \mathrm{Se}, \mathrm{Si}, \mathrm{Sn}, \mathrm{Tl}, \mathrm{U}, \mathrm{V}, \mathrm{Y}$ and $\mathrm{Zn}$ species from aqueous solutions in $0.1 \mathrm{~mol} \mathrm{~L}^{-1} \mathrm{NaOH}$ was also investigated, but only $\mathrm{Hg}$ produced an ICP OES signal. The presence of these elements in solution did not influence the $\mathrm{Hg}$ signal, even at added concentrations of $1000 \mu \mathrm{g} \mathrm{L}^{-1}$.

The procedure was applied to the analysis of other environmental certified samples, including river and marine sediments as well as sewage sludge, but the recovery was too low, between $20 \%$ and $70 \%$. This may be explained because the addition of $\mathrm{NaOH}$ resulted in the formation of hydrous oxides and hydroxides from concomitants in the sample solution which produced a gelatinous precipitate that occluded $\mathrm{Hg}^{0}$ and $\mathrm{Hg}^{2+}$.

Several alternative strong bases were also examined for their efficiency of cold vapor generation, including 0.1 mol L-1 solutions of hydroxides of $\mathrm{K}^{+}, \mathrm{Ca}^{2+}, \mathrm{Mg}^{2+}$ and $\mathrm{NH}_{4}^{+}$. Approximately the same signal intensity was obtained for all bases, except for $\mathrm{NH}_{4} \mathrm{OH}$, for which the intensity was about half.
Aqueous solutions of thimerosal $\left(\mathrm{C}_{9} \mathrm{H}_{9} \mathrm{HgNaO}_{2} \mathrm{~S}\right)$ and ethanolic solutions of methylmercury $\left(\mathrm{CH}_{3} \mathrm{HgCl}\right)$, containing $10 \mu \mathrm{g} \mathrm{L}^{-1}$ total $\mathrm{Hg}$ were mixed with different proportions of an aqueous standard solution of $\mathrm{Hg}^{2+}$. The mixtures were (or not) submitted to acid digestion in a microwave oven. The results are shown in Table 3. It was found that, without digestion, only $\mathrm{Hg}^{2+}$ was detected, while after digestion both were detected. Only $\mathrm{Hg}^{2+}$ appears to lead to the formation of $\mathrm{Hg}^{0}$ by reduction with $\mathrm{NaOH}$, while other $\mathrm{Hg}$ species do not respond.

Table 3. Analytical results for spiked and digested thimerosal and methylmercury solutions, $10 \mu \mathrm{g} \mathrm{L}^{-1}(n=3)$

\begin{tabular}{lcc}
\hline $\begin{array}{l}\text { Spike } \mathrm{Hg}^{2+} / \\
\left(\mu \mathrm{L} \mathrm{L}^{-1}\right)\end{array}$ & $\begin{array}{c}\mathrm{MeHg} / \\
\left(\mu \mathrm{g} \mathrm{L}^{-1}\right)\end{array}$ & $\begin{array}{c}\text { Thimerosal/ } \\
\left(\mu \mathrm{g} \mathrm{L}^{-1}\right)\end{array}$ \\
\hline 0 (with digestion) & $10.3 \pm 0.7$ & $9.2 \pm 0.2$ \\
5 (with digestion) & $15.2 \pm 0.2$ & $14.5 \pm 0.4$ \\
10 (with digestion) & $20.5 \pm 0.4$ & $21.7 \pm 0.4$ \\
0 (without digestion) & $\mathrm{ND}$ & $\mathrm{ND}$ \\
5 (without digestion) & $5.2 \pm 0.2$ & $4.7 \pm 0.3$ \\
10 (without digestion) & $9.8 \pm 0.3$ & $10.5 \pm 0.1$ \\
\hline
\end{tabular}

ND: not detectable at level of $0.4 \mu \mathrm{g} \mathrm{L}^{-1}$.

The signal intensity arising from vapor generation by the addition of only $\mathrm{NaOH}$ to an aqueous standard solution containing $\mathrm{Hg}^{2+}$ is about five-fold lower than that arising from the addition of $\mathrm{NaBH}_{4}$ and $\mathrm{HCl}$ in the traditional online flow injection manifold using a strong reducing agent. Certainly, the presence of a reducing agent enhances the rate of reduction and its efficiency, providing a much higher intensity signal.

\section{Conclusions}

Aqueous inorganic mercury can be reduced to $\mathrm{Hg}^{0}$ by the single addition of $\mathrm{NaOH}$ (in the absence of any further reducing agent such as $\mathrm{NaBH}_{4}$ or $\mathrm{SnCl}_{2}$ ). The mechanism of reduction is not yet known, but requires a high $\mathrm{pH}$, most probably indicating production of the $\mathrm{Hg}^{0}$ from $\mathrm{Hg}(\mathrm{OH})_{2}$. This new finding was applied to the determination of total $\mathrm{Hg}$ in digested biological samples by simply treating them with $\mathrm{NaOH}$. Only $\mathrm{Hg}^{2+}$ can be converted to $\mathrm{Hg}^{0}$, any organo-mercury species present must be decomposed 
before being treated with $\mathrm{NaOH}$. This observation opens the possibility for development of a rapid and easy speciation methodology for mercury. The procedure can likely be improved by designing a more efficient vapor generation apparatus, by accelerating reduction/phase separation steps by heating or sonication and/or by collecting the vapor before measurement (i.e., trapping on gold).

\section{Acknowledgments}

The authors are thankful to Conselho Nacional de Desenvolvimento Científico e Tecnológico (CNPq, Brazil) for financial support and for A. J. Curtius scholarship.

\section{References}

1. Takase, I.; Pereira, H. B.; Luna, A. S.; Grinberg, P.; Campos, R. C; Quim. Nova 2002, 25, 1132.

2. Pohl, P.; Trends Anal. Chem. 2004, 23, 21.

3. Pohl, P.; Trends Anal. Chem. 2004, 23, 87.

4. Hywel, E. H.; Day, J. A.; Fisher, A.; Price, W. J.; Smith, C. M. M.; Tyson, J. F.; J. Anal. At. Spectrom. 2004, 19, 775.

5. Bolea, E.; Laborda, F.; Castillo, J. R.; Sturgeon, R. E.; Spectrochim. Acta, Part B 2004, 59, 505.

6. Guo, X.; Sturgeon, R. E.; Mester, Z.; Gardner, G. J.; Anal. Chem. 2003, 75, 2092.
7. Guo, X.; Sturgeon, R. E.; Mester, Z.; Gardner, G. J.; Appl. Organomet. Chem. 2004, 18, 205.

8. Capelo, J. L.; Maduro, C.; Mota, A. M.; J. Anal. At. Spectrom. 2004, 19, 414.

9. Tsalev, D. L.; J. Anal. At. Spectrom. 1999, 14, 147.

10. Long, Z.; Xin, J.J.; Hou, X. D.; Spectrosc. Lett. 2004, 37, 263.

11. Han, C.; Zheng, C.; Wang, J.; Cheng, G.; Lv, Y.; Hou, X.; Anal. Bional. Chem. 2007, 388, 825.

12. Yin, Y.; Qiu, J.; Yang, L.; Wang, Q.; Anal. Bional. Chem. 2007, $388,831$.

13. Vieira, M. A.; Ribeiro, A. S.; Curtius, A. J.; Sturgeon, R. E.; Anal. Bional. Chem. 2007, 388, 837.

14. Ribeiro, A. S.; Vieira, M. A.; Willie, S.; Sturgeon, R. E.; Anal. Bional. Chem. 2007, 388, 849.

15. Gil, S.; Lavilla, I.; Bendicho, C.; Anal. Chem. 2006, 78, 6260.

16. Feng, Y. -L.; Lam, J. W.; Sturgeon, R. E.; Spectrochim. Acta, Part B 2004, 59, 667.

17. Miller, J. N.; Miller, J. C.; Statistics and Chemometries for Analytical Chemistry, $4^{\text {th }}$ ed., Person Education: England, 2000.

Received: October 23, 2007

Web Release Date: April 25, 2008 